\title{
Effective connectivity of LSD-induced ego dissolution
}

4 Devon Stoliker ${ }^{1^{*}}$, Leonardo Novelli ${ }^{1}$, Franz X. Vollenweider ${ }^{3}$, Gary F. Egan $^{1,2}$, Katrin H. Preller ${ }^{3+}$, and Adeel Razi ${ }^{1,2,4,5+}$

14 + Joint Senior Authors

$15 *$ Corresponding author

16 Name: Devon Stoliker

17 Address: Monash Biomedical Imaging,

18 762-772 Blackburn Rd,

19 Clayton VIC 3168. Australia.

20 Email: devon.stoliker@monash.edu

21

22 Keywords: Ego dissolution; LSD; resting state functional MRI; dynamic causal modelling;

23 predictive coding

26 Abstract: 
medRxiv preprint doi: https://doi.org/10.1101/2021.12.28.21268391; this version posted January 3, 2022. The copyright holder for this preprint (which was not certified by peer review) is the author/funder, who has granted medRxiv a license to display the preprint in perpetuity.

It is made available under a CC-BY-NC 4.0 International license .

28 Classic psychedelic-induced ego dissolution involves a shift in the sense of self and blurring of boundary

29 between the self and the world. A similar phenomenon is identified in psychopathology and is associated

30 to the balance of anticorrelated activity between the default mode network (DMN) -

31 which directs attention inwards - and the salience network $(\mathrm{SN})$ - which recruits the dorsal attention

32 network (DAN) to direct attention outward. To test whether change in anticorrelated networks underlie

33 the peak effects of LSD, we applied dynamic causal modeling to infer effective connectivity of resting

34 state functional MRI scans from a study of 25 healthy adults who were administered 100mg of LSD, or

35 placebo. We found that change in inhibitory effective connectivity from the SN to DMN became

36 excitatory, and inhibitory effective connectivity from DMN to DAN decreased under the peak effect of

37 LSD. These changes in connectivity reflect diminution of the anticorrelation between resting state

38 networks that may be a key neural mechanism of LSD-induced ego dissolution. Our findings suggest the

39 hierarchically organised balance of resting state networks is a central feature in the construct of self.

40

\section{Significance:}

42

43 The findings can inform the parallel between the maintenance of subject-object boundary and changes to

44 anticorrelated canonical resting state brain networks. Effective connectivity informs the hierarchical

45 organisation of brain networks underlying modes of perception. Moreover, the anticorrelation of brain

46 networks is an important measure of mental function. Understanding the neural mechanisms of

47 anticorrelation change under psychedelics help identify its relationship to psychosis and its association to

48 psychedelic assisted therapeutic outcomes.

50 Keywords - fMRI, psychedelics, resting state connectivity, Dynamic causal modelling, LSD, ego dissolution

\section{Introduction:}


medRxiv preprint doi: https://doi.org/10.1101/2021.12.28.21268391; this version posted January 3, 2022. The copyright holder for this preprint (which was not certified by peer review) is the author/funder, who has granted medRxiv a license to display the preprint in perpetuity.

It is made available under a CC-BY-NC 4.0 International license .

54 Classic psychedelics are powerful substances with low toxicity that can temporarily alter brain activity

55 and produce profound changes to consciousness (Carhart-Harris, 2018; Johnson, Richards, \& Griffiths,

56 2008; Preller \& Vollenweider, 2018; F. X. Vollenweider, 1998; F. X. Vollenweider et al., 1997).

57 Historical use of their mind altering effects that are undergoing translation into modern clinical therapies

58 may constitute a crucial component of their therapeutic efficacy (Roseman, Nutt, \& Carhart-Harris, 2018;

59 Yaden \& Griffiths, 2020). The subjective effects of classic psychedelics are characterised by ego

60 dissolution (Preller \& Vollenweider, 2018; Stoliker, Egan, Friston, \& Razi, 2021), described as the shift

61 in the sense of self and a loss of boundary between the subjective and the objective world (Dittrich, 1998;

62 Studerus, Gamma, \& Vollenweider, 2010; Vollenweider and Smallridge, 2021; Grof, 1980; Lebedev et

63 al., 2015). Ego dissolution is a validated construct (Dittrich, 1998; Matthew M. Nour, Evans, Nutt, \&

64 Carhart-Harris, 2016; Studerus et al., 2010) and is thought to involve changes to resting state network

65 (RSN) activity (Müller, Dolder, Schmidt, Liechti, \& Borgwardt, 2018; Preller et al., 2018; Stoliker et al., 66 2021).

67

68 Functional magnetic resonance imaging (fMRI) investigations indicate activity across the brain is

69 functionally integrated and forms multiple RSNs (Raichle, 2015). RSNs are associated to mental activity

70 and the balance of connectivity between them is associated to the direction of conscious attention

71 (Michael D. Fox et al., 2005; K. J. Friston, 2011; Greicius \& Menon, 2004). The default mode network

72 (DMN) composed of the medial prefrontal cortex (mPFC), posterior cingulate cortex (PCC), and

73 (bilateral) angular gyrus (AG) is a RSN that activates primarily in the absence of immediate external goal-

74 directed attention (Raichle et al., 2001). Its function in self-focused thinking and attention suggests its

75 close relationship to the ego (Andrews-Hanna, Smallwood, \& Spreng, 2014). In contrast, the dorsal

76 attention network (DAN) is a RSN activated during external-focused task-driven attention (Corbetta \&

77 Shulman, 2002; Michael D. Fox \& Raichle, 2007) and is usually considered to be composed of the frontal

78 eye field (FEF) and intraparietal sulcus (IPS) bilaterally. The activity of the DMN and DAN are identified

79 as anticorrelated and predictably alternate with the inward or outward switching of attention (Michael D. 
medRxiv preprint doi: https://doi.org/10.1101/2021.12.28.21268391; this version posted January 3, 2022. The copyright holder for this preprint (which was not certified by peer review) is the author/funder, who has granted medRxiv a license to display the preprint in perpetuity.

It is made available under a CC-BY-NC 4.0 International license .

Fox et al., 2005). The DMN-DAN anticorrelation can be hypothesised to be a mechanism maintaining the

81 boundary between the subject (observer) and object (observation) that is altered during experiences of

82 psychedelic ego dissolution.

84 A third resting state network, the salience network ( $\mathrm{SN})$, acts as the switching mechanism coordinating

85 the direction of attention between internal and external stimuli (Liang et al., 2015; Seeley et al., 2007).

86 The SN's cardinal regions are the dorsal anterior cingulate cortex (dACC) and anterior insula (AI). Both

87 the dACC and AI are consistently coactivated across cognitive tasks (Swick, Ashley, \& Turken, 2011),

88 however the dACC is more involved in response selection and conflict monitoring (Ide, Shenoy, Yu, \&

$89 \mathrm{Li}, 2013$; Menon, 2011) while the AI receives greater multimodal sensory input (Averbeck \& Seo, 2008)

90 (Vogt \& Pandya, 1987), detects behaviourally relevant stimuli (Menon, 2015) and coordinates the

91 dynamic interactions of anticorrelated networks (Menon \& Uddin, 2010; Sridharan, Levitin, \& Menon,

92 2008).

94 Coordinated interactions between these networks produce important biopsychological functions. SN

95 coactivation with the DAN detects bottom-up features in the visual environment that are infrequent or

96 biologically significant (Egner et al., 2008; Fecteau \& Munoz, 2006; Szczepanski, Pinsk, Douglas,

97 Kastner, \& Saalmann, 2013) and also enables the detection of resources relevant to higher-order goals

98 (Menon, 2015). Furthermore, anticorrelated function between the SN and DMN is a biomarker of

99 efficient cognition (Chand, Wu, Hajjar, \& Qiu, 2017; Putcha, Ross, Cronin-Golomb, Janes, \& Stern,

100 2016). Trauma to the white matter tracts within the SN that connect the rAI and dACC predicts

101 dysregulated DMN function (Bonnelle et al., 2012). Importantly, abnormality of SN connectivity and its

102 anticorrelated interactions is indicative of schizophrenia (Manoliu et al., 2014), psychosis (Palaniyappan

103 \& Liddle, 2012; Wotruba et al., 2013) and internalizing disorders (Peterson, Thome, Frewen, \& Lanius,

104 2014) (See Menon 2015 for review of SN associations to psychopathology) (Menon, 2011). 
medRxiv preprint doi: https://doi.org/10.1101/2021.12.28.21268391; this version posted January 3, 2022. The copyright holder for this preprint (which was not certified by peer review) is the author/funder, who has granted medRxiv a license to display the preprint in perpetuity.

It is made available under a CC-BY-NC 4.0 International license.

The DMN and SN have been previously investigated in relation to unique senses of self. The $\mathrm{SN}$ has been suggested to be involved in an aspect of the self defined as the basic sense of being rooted within a body, termed the minimal or embodied self (Blanke \& Metzinger, 2009; Lebedev et al., 2015; Legrand \& Ruby, 2009). This association is supported by changes to the SN documented in psychopathology (Liu et al., 2018), meditation (Doll, Hölzel, Boucard, Wohlschläger, \& Sorg, 2015; Ramirez Barrantes et al., 2019)

111 and psychedelic-induced ego dissolution (Lebedev et al., 2015) (see Supplementary Table 1 for a subset

112 of psychedelic findings related to networks and regions of interest). The pre-reflective qualities that

113 define the minimal self have also been suggested as antecedents of the narrative aspect of self (Ho,

114 Preller, \& Lenggenhager, 2020; M. M. Nour \& Carhart-Harris, 2017). The narrative aspect of self is 115 believed to be under the control of the DMN and describes self-related mental activity and personal 116 identity (Metzinger, 2003; Millière, 2017) that strongly parallels the classic Freudian construct of ego

117 (Carhart-Harris \& Friston, 2010; Cieri \& Esposito, 2019). These parallels have led to exploratory investigations of the DMN under psychedelic-induced ego dissolution that indicate a general pattern of reduced connectivity (Carhart-Harris \& Friston, 2010; Cieri \& Esposito, 2019; Ruban \& Kolodziej, 2018;

122 Reduced DMN activity has also been identified in meditation and is a feature of improved mental health

123 (Batchelor, 2008; Judson A. Brewer et al., 2011; Hasenkamp, Wilson-Mendenhall, Duncan, \& Barsalou,

124 2012; Millière, Carhart-Harris, Roseman, Trautwein, \& Berkovich-Ohana, 2018). Psychedelics have been

125 reported to reduce symptoms of patients experiencing internalising mental health disorders (Carhart-

126 Harris et al., 2018; Nutt \& Carhart-Harris, 2020; Ruban \& Kolodziej, 2018). Altered self-boundaries may

127 be important to these therapeutic outcomes (Griffiths et al., 2016; Roseman et al., 2018; Ross et al.,

128 2016). Nascent alignment between the free energy principle and psychoanalytic processes proposes that

129 high-order, secondary processes of the ego function to minimise free energy of lower-orders (Cieri \&

130 Esposito, 2019; Karl Friston, 2009; K. Friston, Kilner, \& Harrison, 2006; Herzog et al., 2020).

131 Psychedelic-induced free energy increase in networks such as the DMN is suggested to disinhibit high 
medRxiv preprint doi: https://doi.org/10.1101/2021.12.28.21268391; this version posted January 3, 2022. The copyright holder for this preprint (which was not certified by peer review) is the author/funder, who has granted medRxiv a license to display the preprint in perpetuity.

It is made available under a CC-BY-NC 4.0 International license.

order inhibitory selection of bottom-up channels and enable consideration of alternate hypotheses underlying making sense of the world (Carhart-Harris \& Friston, 2019; Safron, 2021; Stoliker et al., 2021). These mechanisms may broadly account for experiences of ego dissolution (Stoliker, Egan, \&

135 Razi, 2021). An early interpretation of psychedelics noted in filtration theory similarly suggests

136 improvements follow psychedelic reduction of ego-protective defenses (Connolly, 2018; Freud, 1894;

137 Stoliker et al., 2021; Swanson, 2018). Understanding network changes in ego dissolution may inform how

138 network interactions relate to clinical outcomes. Meditation is also recognised for its benefits to wellbeing

139 and resembles a similar trajectory of ego disarmament by seeking cessation of the self (Batchelor, 2008;

140 Millière et al., 2018). The practice of meditation has demonstrated clinical utility (Goyal et al., 2014) and

141 can enhance wellbeing by altering the relationship between self and other (Dambrun, 2017). Pertinently, a

142 form of meditation termed nondual awareness meditation reduces the anticorrelation of extrinsic and

143 intrinsic activated brain regions and produces a subjective experience of dissolving subject-object

144 boundaries (Josipovic, Dinstein, Weber, \& Heeger, 2012). These findings indicate anticorrelation under

145 control of the $\mathrm{SN}$ as a neural mechanism that underlies ego dissolution.

147 Anticorrelation between the DMN and task positive networks under psilocybin has previously been 148 investigated with the findings demonstrating reduced anticorrelation when participants experienced ego 149 dissolution, under psilocybin (intravenous infusion, $2 \mathrm{mg}$ dissolved in 10ml) (Carhart-Harris et al., 2012). 150 However, a similar investigation, under ayahuasca (oral brew, 2.2. mL/kg body weight, containing 0.8 $151 \mathrm{mg} / \mathrm{ml}$ DMT and $0.21 \mathrm{mg} / \mathrm{ml}$ harmine) failed to identify anticorrelation changes (Palhano-Fontes et al., 152 2015). The inability of functional connectivity analyses to determine the direction of connectivity 153 between networks in these studies suggests the value of adopting mechanistic approaches to determine 154 changes in effective connectivity of networks under psychedelics. Dynamic Causal Modeling (DCM) is a 155 Bayesian method of inference based on task based or resting state fMRI time series activity of brain 156 regions (K. J. Friston, Harrison, \& Penny, 2003; Karl J. Friston, Kahan, Biswal, \& Razi, 2014). DCM can 157 disentangle hierarchical RSN and regional interactions by determination of the directionality of 
medRxiv preprint doi: https://doi.org/10.1101/2021.12.28.21268391; this version posted January 3, 2022. The copyright holder for this preprint (which was not certified by peer review) is the author/funder, who has granted medRxiv a license to display the preprint in perpetuity.

It is made available under a CC-BY-NC 4.0 International license.

connectivity. DCM has been previously applied to investigate thalamic connectivity to the cortex under

LSD (Preller et al., 2019) that indicated the SN is at the apex of the DMN and DAN triple network

hierarchy (Zhou et al., 2018). The SN's position in this hierarchy and its mediating role to control the

161 switching of DAN and DMN activity suggests that change to the SN by psychedelics may influence their

162 patterns of anticorrelated activity. The SN and DMN share associations to aspects of self and the

163 importance of their connectivity in psychopathology suggests change in their connectivity may be a

164 mechanism of ego dissolution that underlies a shift in the sense of self (Northoff et al., 2006; Scalabrini et

165 al., 2020).

Therefore, to understand the neural mechanisms of ego dissolution and inform the biological basis of the subject-object relationship, the directed changes to these networks under the classic psychedelic lysergic acid diethylamide (LSD) was investigated. LSD effects were examined across placebo (two weeks apart from LSD administration), peak effects at 75 minutes and later effects at 300 minutes post LSD

171 administration using DCM analysis to reveal regional and network connectivity changes. Ego dissolution

172 (quantified as oceanic boundlessness $(\mathrm{OBN})$ ) was measured on the five dimensions of altered states of

173 consciousness scale (5D-ASC) (Studerus et al., 2010). Based on previous research that associated the

174 networks under investigation to self and subject-object boundaries, we hypothesised the association

175 between effective connectivity would change during the peak effects of LSD and ego dissolution. DMN-

176 DAN was tested for change to subject-object boundaries and SN-DMN was tested for change to the self.

177 However, the direction of excitatory-inhibitory connectivity change remained exploratory. Additionally,

178 we measured connectivity of regions composing the networks of interest and the (hierarchical)

179 connectivity strength between networks.

181 Results: 
medRxiv preprint doi: https://doi.org/10.1101/2021.12.28.21268391; this version posted January 3, 2022. The copyright holder for this preprint (which was not certified by peer review) is the author/funder, who has granted medRxiv a license to display the preprint in perpetuity.

It is made available under a CC-BY-NC 4.0 International license .

Functional connectivity changes

186 Functional connectivity across groups demonstrated a fading of the pattern of anticorrelation between

187 DMN and DAN and SN, from placebo to peak effects of LSD before showing evidence of restoration in

188 the later effects at 300 minutes. Group level regional functional connectivity matrix across each condition

189 (placebo, 75 minutes after LSD administration and 300 minutes post LSD administration) is provided in

190 Supplementary Fig. 1.

191

192 Between networks changes in effective connectivity

193 The first resting-state fMRI scan was done 75 minutes post administration of LSD which is during the

194 peak effects of LSD. The connectivity strength between networks was computed as the difference

195 between averaged and unsigned efferent and afferent connection parameters between networks (see

196 methods for further details) (Zhou et al., 2018). As shown in Fig. 1a), at this time, group level, between

197 networks, effective connectivity increased from the SN to DMN causing the directed connection to

198 become excitatory. A similar change was observed in the excitatory connectivity from the DMN to the

199 DAN resulting in reduced inhibitory connectivity (see Fig. 1c). SN to DMN and DMN to DAN changes

200 from placebo are greatest during the peak effects at 75 minutes and reduce in the later effects at 300

201 minutes (see Fig. 1a) and 1b). These changes show reduced hierarchical connectivity strength (i.e.,

202 increased afferent connections) of the SN and increased hierarchical connectivity strength (i.e., increased

203 efferent connections) of the DMN and DAN from placebo $(\mathrm{SN}=-1.16 \mathrm{~Hz}, \mathrm{DMN}=+0.32 \mathrm{~Hz}, \mathrm{DAN}=$ 
medRxiv preprint doi: https://doi.org/10.1101/2021.12.28.21268391; this version posted January 3, 2022. The copyright holder for this preprint (which was not certified by peer review) is the author/funder, who has granted medRxiv a license to display the preprint in perpetuity.

It is made available under a CC-BY-NC 4.0 International license .

$204+0.41 \mathrm{~Hz}$, see Supplementary S4 for explanation and quantitative analysis).

1a)
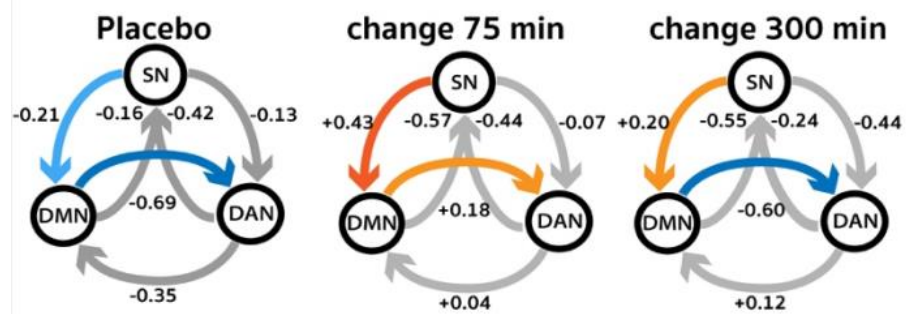

205

206

207

208

209

210

211

212

213

214

215

216

217

218

219 connections in $\mathrm{Hz}$. All results are for posterior probability $>0.99$.

Between regions changes in effective connectivity. connectivity matrices across conditions). 1b)

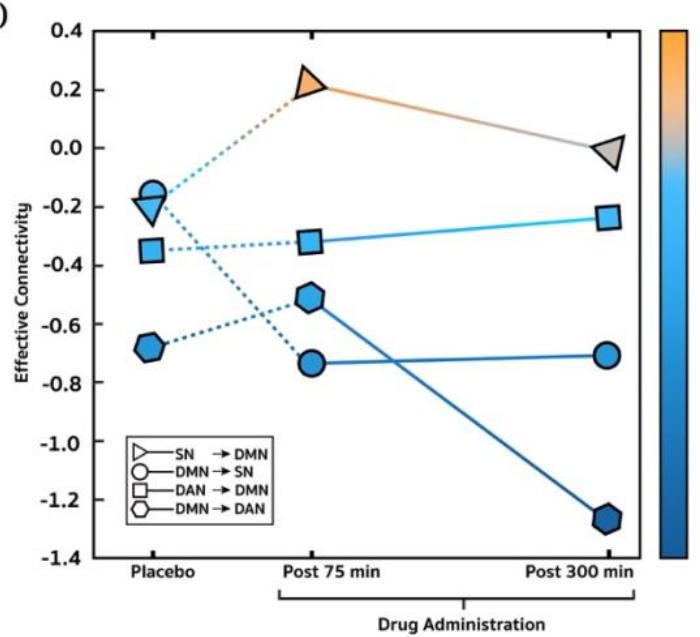

Fig 1. Network effective connectivity change under peak effects of LSD. a) Highlighted connections show

changes in effective connectivity compared to placebo signifying peak effect. b) Network effective connectivity change graphed across placebo, peak effects and later effects. Same data as a) and b) but plotted as a line graph for better visualization. Values display effect sizes (posterior expectations) of

Between regions effective connectivity that underly the SN to DMN changes include increased inhibitory self-connectivity of the dACC and IFEF and effective connectivity from the 1AG to rAG, lFEF to the lIPS, IIPS to rAI. These regions are highlighted because the change in their effective connectivity show large effect sizes during the peak effects than in later effects of LSD. Moreover, 1AI to dACC and rAG to rAI effective connectivity show large effect size change from inhibitory in the peak effects of LSD to excitatory in the later effects (see Fig. 2, panel a) below and Supplementary Fig. 3 for untranslated effective 
a)

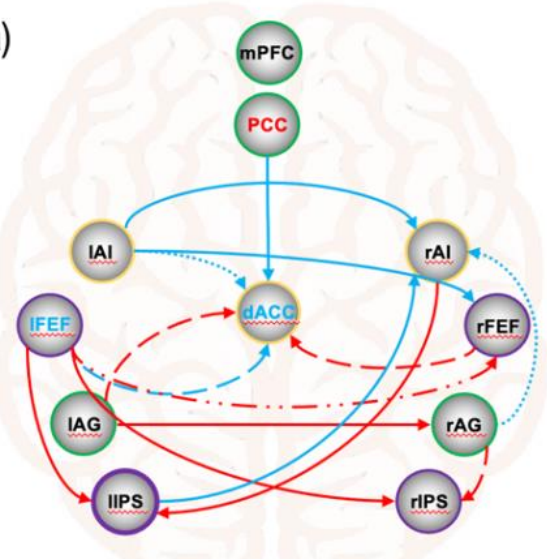

b)

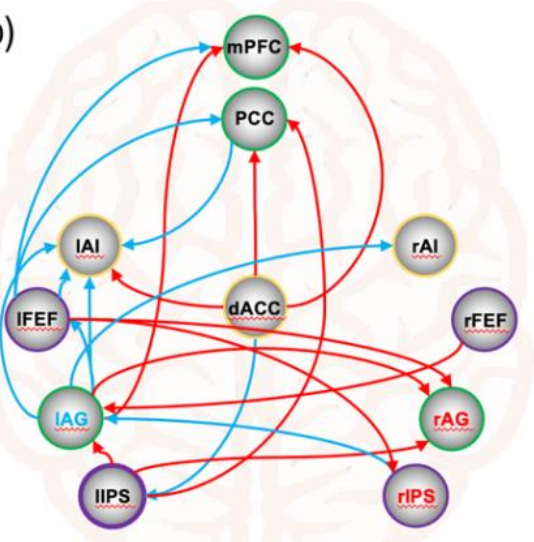

Legend

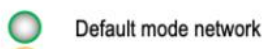

Salience network

Dorsal attention network

Panel a)

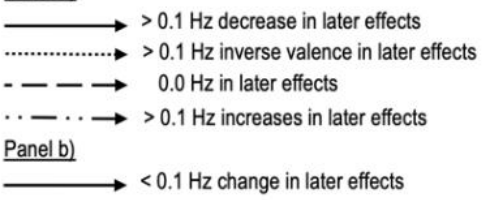

221 Fig 2. Region effective connectivity signifying a) peak and b) lasting effects of LSD. Red lines and lettering

222 indicate excitatory change; blue lines and lettering indicate inhibitory change. Only connections with

223 change from placebo to 75 minutes post $L S D>0.1 \mathrm{~Hz}$ are included. Panel a) illustrates effective

224 connectivity with change $>0.1 \mathrm{~Hz}$ from peak effects at 75 minutes to the later effects at 300 minutes,

225 signifying connectivity unique to the peak effects of LSD. See Supplementary Table 2 for posterior

226 expectations (effect sizes) and credible intervals. Panel b) illustrates effective connectivity with change <

$2270.1 \mathrm{~Hz}$ from peak effects at 75 minutes to the later effects at 300 minutes, signifying connectivity

228 changes that last over the effects of LSD. See Supplementary Table 3 for posterior expectations (effect

229 size) and credible intervals. All results are for posterior probability $>0.99$.

\section{$231 \quad$ Lasting effects}

232 Between networks changes in effective connectivity.

233 LSD effects are also distinguished by changes from placebo that last across time under LSD. Increased

234 DAN to DMN and decreased DMN to SN effective connectivity at 75 minutes remains evident 300 minutes

235 after LSD (see Fig. 1, panel a) above, and see Supplementary Fig. 3 for effect size and posterior 236 probabilities). 
medRxiv preprint doi: https://doi.org/10.1101/2021.12.28.21268391; this version posted January 3, 2022. The copyright holder for this preprint (which was not certified by peer review) is the author/funder, who has granted medRxiv a license to display the preprint in perpetuity.

It is made available under a CC-BY-NC 4.0 International license .

Between regions changes in effective connectivity.

239 Effects lasting across time under LSD are identified by change in 1AG and rIPS self-inhibition, IFEF to

240 mPFC inhibition and IIPS to PCC excitation. These connections show large effect sizes from placebo to

241 peak effect that remain to the later effects of LSD (see Fig. 2, panel b) above and Supplementary Fig. 3 for

242 untranslated effective connectivity matrices across conditions).

244 The results demonstrate increased effective connectivity of the DMN to DAN and SN to the DMN during

245 the peak effects of LSD. These changes correspond with reduced SN hierarchical connectivity strength (i.e.,

246 increased afferent connections) and coincide with a fading of the functional anticorrelation (see

247 Supplementary Fig. 1 for functional connectivity results).

249 Discussion:

251 This investigation seeks to understand how effective connectivity between anticorrelated large-scale brain

252 networks is related to ego dissolution. Our analysis reveals between network effective connectivity changes

253 that occur with a diminution of the pattern of anticorrelation under the peak effects of LSD. Bidirectional

254 changes in effective connectivity between the DMN and DAN were investigated for their relationship to

255 subject-object boundaries. We identified reduced inhibition of the DMN to the DAN under the peak effects

256 of LSD. The reduced inhibition is largely lost in the later effects, when ego dissolution dissipates. This

257 indicates reduced inhibition of the DMN to DAN as a feature of peak LSD effects that may relate to the

258 fading of the functional anticorrelation between the two networks. Reduced DMN to DAN inhibition may

259 also represent an increased transmission and connection of the narrative self to the sense of object.

260 Moreover, hierarchical organisation and strength of networks were calculated using efferent vs afferent

261 connections (Zhou et al., 2018). The DMN and DAN showed increased hierarchical connectivity strength

262 during the peak effects of LSD and segregate from SN, under the peak effects of LSD (See Supplementary 
medRxiv preprint doi: https://doi.org/10.1101/2021.12.28.21268391; this version posted January 3, 2022. The copyright holder for this preprint (which was not certified by peer review) is the author/funder, who has granted medRxiv a license to display the preprint in perpetuity.

It is made available under a CC-BY-NC 4.0 International license .

S4). The increase in hierarchical connectivity strength of the DMN and DAN reinforces evidence of their fading anticorrelation that may contribute to the dissolution of the boundary between the subject and the object. The opposite effective connectivity from DAN to DMN also displays reduced inhibition under LSD. However, this change remains over the course of time suggesting it is not a primary mechanism of the reduced functional anticorrelation between them or ego dissolution.

Network level DMN-DAN changes are supported by the lAG to rAG connectivity. The AG serves functions in autobiographical memory and bodily awareness (Bréchet, Grivaz, Gauthier, \& Blanke, 2018).

271 AG also operates complex language functions and makes meaning out of visually perceived self-related

272 words (Yaoi, Osaka, \& Osaka, 2015). Excitatory change in the connection from IAG to rAG in placebo to

273 the peak effects of LSD is greater than in the later effects suggesting the importance of this connection in

274 the peak effects.

275

276 Inclusion of the $\mathrm{SN}$ in this analysis enabled measurement of its effective connectivity to the DMN and

277 DAN under LSD. The change to the coordinated balance of networks, under the control of SN, by LSD

278 may be an important but overlooked neural mechanism of ego dissolution suggested by the superiority of

279 SN in this hierarchy of triple networks (Zhou et al., 2018). Previous reports of reduced anticorrelation

280 (Carhart-Harris et al., 2012), reduced SN integrity (Lebedev et al., 2015) in occurrences of ego

281 dissolution, and its hypothesised function in basic conscious-awareness also indicate the value of

282 measuring SN connectivity in the anticorrelation between DMN and DAN. Moreover, ego dissolution has

283 previously been suggested to involve the breakdown of sub-personal processes underlying the minimal

284 self, a suggestion that is consistent with Bayesian models of phenomenal selfhood in which the subjective

285 structure of conscious experience is determined from the optimisation of prediction in perception and

286 action (Clark, 2013; Karl Friston, 2010; Millière, 2017). The change in the SN effective connectivity

287 under the peak effects of LSD is our most pronounced finding. SN connectivity to the DMN changes 
medRxiv preprint doi: https://doi.org/10.1101/2021.12.28.21268391; this version posted January 3, 2022. The copyright holder for this preprint (which was not certified by peer review) is the author/funder, who has granted medRxiv a license to display the preprint in perpetuity.

It is made available under a CC-BY-NC 4.0 International license.

suggests SN connectivity change to the DMN is mechanistic in the peak effects of LSD and may indirectly influence the DMN-DAN interactions. The opposite connection, the DMN to SN, shows an inverse pattern of change from placebo, suggesting reduced DMN influence over the SN which lasts over time. The SN to DMN connectivity change may therefore be a more likely mechanism of ego dissolution representing a quietening of narrative self in the peak effects of LSD that reduces in the later effects. This change in DMN function to minimise free energy and suppress prediction errors that in Freudian terms may liberate the ego from the reality principle (Carhart-Harris \& Friston, 2010; Cieri \& Esposito, 2019). SN to DMN change is accompanied by reduced hierarchical connectivity strength of the $\mathrm{SN}$ that is characterised by increased SN afferent connections and increased DMN efferent connections. The SN has previously been identified to be hierarchically superior to the DMN and DAN (Zhou et al., 2018). We demonstrate the divergence of SN and DMN hierarchical strength under the peak effects of LSD shift the hierarchical order of the SN beneath the DMN.

The changes to region level effective connectivity underlying the SN are demonstrated by dACC selfconnectivity under the peak effects of LSD. The dACC is a central brain hub involved in cognitive functions, social emotions (Andrews-Hanna et al., 2014; Etkin, Egner, \& Kalisch, 2011; Preller et al., 2015) and performance monitoring (Ham et al., 2014) and has previously been noted in social cognition under psilocybin (Preller et al., 2016). Enlargement of the ACC has also been reported after regular use of ayahuasca (Carlos Bouso et al., 2015). We find dACC self-connectivity inhibition and inhibitory connectivity from the 1AI to the dACC under the peak effects of LSD, compared to placebo. In the later effects dACC inhibition become less inhibitory while the 1AI changes to excitatory. The AI is involved in interoceptive awareness (Chong, $\mathrm{Ng}$, Lee, \& Zhou, 2017) and the shift of internal and external perception

311 (Menon \& Uddin, 2010; Sridharan et al., 2008). Damage to SN connectivity predicts dysregulated DMN 312 function (Menon, 2011) and alteration of SN anticorrelated interactions share association with psychosis 313 and internalising disorders (Bonnelle et al., 2012). dACC and 1AI inhibition at the peak effects of LSD may 314 indicate the role of SN inhibition that is relevant to ego dissolution and psychedelic assisted therapy. 
medRxiv preprint doi: https://doi.org/10.1101/2021.12.28.21268391; this version posted January 3, 2022. The copyright holder for this preprint (which was not certified by peer review) is the author/funder, who has granted medRxiv a license to display the preprint in perpetuity.

It is made available under a CC-BY-NC 4.0 International license .

Connectivity between the DMN and $\mathrm{SN}$ is also noted in region changes from the rAG to rAI. This connection follows the 1AI to dACC pattern of inhibition in the peak effects and excitation in the later effects, suggesting a reduced influence of the DMN to the SN during peak effects, when ego dissolution occurs that may suggest a shifting sense of self.

The PCC and AACC represent cardinal regions of the DMN and SN respectively and are related to the narrative and minimal aspects of self (Lebedev et al., 2015; Millière, 2017). The connectivity changes between them are reported in association to meditation and the mindfulness capacities of meditators (Judson

323 A. Brewer et al., 2011; Millière et al., 2018; Palhano-Fontes et al., 2015). We provided evidence of the excitation from the dACC to PCC in our effective connectivity analysis under peak effects (see Supplementary Fig. 3), which may suggest dACC cognitive control functions influence on self-related functions of PCC. Interestingly, self-connectivity of the PCC, a hub region of DMN, increases excitation during the peak effects of LSD. PCC involvement in self-awareness is well documented (J. A. Brewer, observed to decrease under psychedelics (see Supplementary Table 1).

331 Other notable regions in our analysis include the FEF and IPS. The FEF operates visual attention 332 (Thompson, Biscoe, \& Sato, 2005) and the IPS serves functions directing attention and memory (Corbetta 333 \& Shulman, 2002; Michael D. Fox, Corbetta, Snyder, Vincent, \& Raichle, 2006). The nearby right inferior 334 parietal lobule (rIPL) is also associated with the sense of agency and self-other discrimination (Chaminade 335 \& Decety, 2002; Lucina Q. Uddin, Molnar-Szakacs, Zaidel, \& Iacoboni, 2006). Smaller effect sizes 336 involving these regions were identified in our analysis (see Supplementary Fig. 3) suggesting more subtle 337 widespread brain changes occur under the effects of LSD.

339 Taken together, under the peak effects of LSD, a strong increase in change of effective connectivity, and a 340 widening of gap between the hierarchical connectivity strength of the SN vs the DMN and DAN shifts in 
medRxiv preprint doi: https://doi.org/10.1101/2021.12.28.21268391; this version posted January 3, 2022. The copyright holder for this preprint (which was not certified by peer review) is the author/funder, who has granted medRxiv a license to display the preprint in perpetuity.

It is made available under a CC-BY-NC 4.0 International license .

341 a direction antithetical to normal hierarchical organisation. This may be said to resemble a collapse - or

342 flattening - of the hierarchy, during peak effects of LSD, when ego dissolution occurs (See Fig. 1 and

343 Supplementary S4). Effective connectivity explains this effect as increased excitatory connectivity from

344 the SN to the DMN. These directed connection changes and the hierarchical strength changes may

345 function to alter the relationship between the minimal and narrative senses of self. The direction of this

346 change suggests the influence of the minimal-self traverses over the narrative-self and may relate to the

347 shift in sense of self described under ego dissolution.

349 Modelling the connectivity of ego dissolution can provide a means to determine the neural mechanisms that

350 underlie the perception of inner and outer reality. The present research establishes important steps to

351 identify the change in network interactions associated with the dichotomy of the subject-object relationship

352 under LSD. The networks involved in this interaction are important in cognitive function and mental

353 wellbeing, suggesting that understanding their change due to psychedelics may elucidate mechanisms of

354 psychedelic clinical therapy. Consideration of practical and theoretical challenges may aid future research

355 directed to study ego dissolution and the anticorrelation between brain networks.

357 Our relatively small sample size $(n=20)$ is clearly a limitation. Sample size and processing pipeline strongly

358 impact the reliability of results. Small sample size may also account for unexpected placebo effective 359 connectivity in our group of subjects. A second practical limitation is the large variance of participant 360 subjective responses to a standard dose of LSD (100mg). Averaging the connectivity of participants 361 experiencing highly variable subjective shifts in consciousness may dilute the effective connectivity 362 representing LSD's subjective effects. An alternative to increased sample size may be predetermining 363 participant dose-response and including only participants with high subjective responses in the analysis.

364 Replicating the investigation of anticorrelated networks with alternate classic psychedelic substances 365 including psilocybin, ayahuasca and mescaline in addition to LSD will be a worthy direction to validate our 366 results. Furthermore, comparisons with similar altered forms of consciousness reporting ego change such 
medRxiv preprint doi: https://doi.org/10.1101/2021.12.28.21268391; this version posted January 3, 2022. The copyright holder for this preprint (which was not certified by peer review) is the author/funder, who has granted medRxiv a license to display the preprint in perpetuity.

It is made available under a CC-BY-NC 4.0 International license .

as psychosis and meditation may also help discern the function of components in the anticorrelated networks.

The selection of regions and region coordinates composing the networks of interest require careful attention.

371 For example, some studies define the DAN as composed by the posterior prefrontal cortex, the inferior

372 precentral sulcus, the superior occipital gyrus, the middle temporal motion complex, and the superior

373 parietal lobule (Andrews-Hanna et al., 2014). Similarly, the DMN may be composed using the inferior

374 parietal lobule (Di \& Biswal, 2014) closely situated to the IPS used in the DAN in this analysis. The

375 composition of regions composing networks can strongly impact results. Furthermore, selection of region

376 centroids can also affect the results. Previous work using this LSD data set used different coordinates for

377 the PCC and identified its increased self-inhibition (Preller et al., 2019), although our analysis identified

378 decreased PCC inhibition. Avoiding this problem is challenging due to anatomical variability between

379 participants, variability in the method of determining coordinates and the selection of regions composing networks. However, the standardisation of these considerations across studies is important to improve the accuracy and reliability of findings across studies.

Future work to extend the current scope of analysis to include connectivity dynamics of additional task positive networks anticorrelated to the DMN and under control of the $\mathrm{SN}$ is required. For example, nonpsychedelic research involving the CEN (central executive network, also known as the frontoparietal central executive network (FPCEN)) has been conducted to investigate schizophrenia (Leptourgos et al., 2020; Menon, 2011), meditation (Doll et al., 2015) and control of attention (Corbetta \& Shulman, 2002). Its importance is further signified by investigations of large-scale network interactions and anticorrelations with the DMN (Andrews-Hanna et al., 2014; Bolton et al., 2020; Menon, 2018). Inclusion of the CEN in anticorrelation investigations may provide a more complete account of anticorrelated network changes 391 associated to ego dissolution. 
medRxiv preprint doi: https://doi.org/10.1101/2021.12.28.21268391; this version posted January 3, 2022. The copyright holder for this preprint (which was not certified by peer review) is the author/funder, who has granted medRxiv a license to display the preprint in perpetuity.

It is made available under a CC-BY-NC 4.0 International license .

Theoretical challenges include consensus on the nature and situation of ego dissolution within the taxonomy

394 of psychedelic-induced effects. Psychometric investigations of psychoanalytic based concepts of ego-

395 functions and measurement of their brain connectivity are recommended future directions. Psychedelics

396 may contribute to these investigations by altering and allowing measurement of brain mechanisms

397 hypothesised to underlie psychoanalytic constructs. Integration of psychoanalytic theory and brain 398 connectivity processes may be important to identifying processes involved in enabling the sense of self and 399 experiences of ego dissolution.

401 Conclusions:

403 The between network balance of anticorrelated activity of specific RSNs depends on subtle adjustments to 404 network activation. Mental wellbeing and efficient cognition rely on the balance of these interactions. LSD 405 appears to shift the balance of network activation and diminish the anticorrelation between brain networks 406 responsible for internal and external modes of perception. Observed increases in effective connectivity from 407 the DMN to DAN and increased hierarchal strength of these networks under peak effects may account for 408 the blurring of boundary between subject and object experienced in ego dissolution. Ego dissolution also 409 involves a shift in the sense of self that may be explained by changes to the interactions between $\mathrm{SN}$ and 410 DMN. These networks are related to distinct aspects of self. Increased effective connectivity from the SN

411 to the DMN and decreased SN hierarchical connectivity strength emphasise hierarchical flattening and

412 increased salience functions reaching the DMN under the peak effects of LSD. Future research could model

413 how changes to these networks effective connectivity may support psychedelic therapeutic outcomes. The

414 neuroscientific study of psychedelic-induced ego dissolution reminds us that constructs and representations

415 of self and internal and external reality exist in connectivity dynamics. This intriguing understanding may

416 inspire future investigations of sentience and consciousness to learn how normal brain function mechanisms

417 contribute to the subject-object relationship and frame our perspective of reality. 
medRxiv preprint doi: https://doi.org/10.1101/2021.12.28.21268391; this version posted January 3, 2022. The copyright holder for this preprint (which was not certified by peer review) is the author/funder, who has granted medRxiv a license to display the preprint in perpetuity.

It is made available under a CC-BY-NC 4.0 International license .

\section{Methods:}

\section{Participants}

422 The data analysed in this paper were collected as part of a larger study (registered at ClinicalTrials.gov

423 (NCT02451072)), which is reported in (Preller et al., 2017) and (Preller et al., 2018), and was approved by

424 the Cantonal Ethics Committee of Zurich. 25 subjects (19 males and 6 females; mean age $=25.24$ y; SD =

$4253.72 \mathrm{y}$; range $=20-34 \mathrm{y})$ were recruited through advertisements at universities in Zurich, Switzerland. All

426 participants were deemed healthy after screening for medical history, physical examination, blood analysis,

427 and electrocardiography. The Mini-International Neuropsychiatric Interview (MINI-SCID), the Diagnostic

428 and Statistical Manual of Mental Disorders, fourth edition self-rating questionnaire for Axis-II personality

429 disorders (SCID-II), and the Hopkins Symptom Checklist (SCL-90-R) were used to exclude subjects with

430 present or previous psychiatric disorders or a history of major psychiatric disorders in first-degree relatives.

431 Participants were asked to abstain from prescription and illicit drug use two weeks prior to first testing and

432 throughout the duration of the study, and abstain from alcohol use 24 hours prior to testing days. Urine tests

433 were also used to exclude pregnancy. Further exclusion criteria included left-handedness, poor knowledge

434 of the German language, cardiovascular disease, history of head injury or neurological disorder, history of

435 alcohol or illicit drug dependence, MRI exclusion criteria, including claustrophobia, and previous

436 significant adverse reactions to a hallucinogenic drug. All participants provided written informed consent

437 statements in accordance with the declaration of Helsinki before participation in the study. Subjects

438 received written and oral descriptions of the study procedures, as well as details regarding the effects and 439 possible risks of drug treatment.

441 Design

442 A double blind, randomized, placebo-controlled, cross-over study was performed. Testing days occurred 443 two weeks apart and participants were orally administered either LSD after pretreatment with $179 \mathrm{mg}$ 
medRxiv preprint doi: https://doi.org/10.1101/2021.12.28.21268391; this version posted January 3, 2022. The copyright holder for this preprint (which was not certified by peer review) is the author/funder, who has granted medRxiv a license to display the preprint in perpetuity.

It is made available under a CC-BY-NC 4.0 International license .

444 Mannitol and $1 \mathrm{mg}$ Aerosil (LSD condition) or $179 \mathrm{mg}$ Mannitol and $1 \mathrm{mg}$ Aerosil after pre-treatment with

$445179 \mathrm{mg}$ Mannitol and $1 \mathrm{mg}$ Aerosil (placebo condition). Resting state scans (10 minutes each) were taken

44675 and 300 minutes following administration.

MRI Data Acquisition and Preprocessing

449 MRI data were acquired on a Philips Achieva 3.0T whole-body scanner. A 32-channel receive head coil

450 and MultiTransmit parallel radio frequency transmission was used. Images were acquired using a whole-

451 brain gradient-echo planar imaging (EPI) sequence (repetition time, 2,500 ms; echo time, $27 \mathrm{~ms}$; slice

452 thickness, $3 \mathrm{~mm}$; 45 axial slices; no slice gap; field of view, $240 \times 240 \mathrm{~mm}^{2}$; in-plane resolution, $3 \times 3 \mathrm{~mm}$;

453 sensitivity-encoding reduction factor, 2.0). Additionally, high-resolution anatomical images (voxel size, 0.7

$454 \times 0.7 \times 0.7 \mathrm{~mm}^{3}$ ) were acquired using a standard T1-weighted 3D magnetization prepared rapid-acquisition

455 gradient echo sequence. The acquired images were analysed using SPM12 (https://www.fil.ion.ucl.ac.uk).

456 The pre-processing steps of the images consisted of slice-timing correction, realignment, spatial

457 normalization to the standard EPI template of the Montreal Neurological Institute (MNI), and spatial

458 smoothing using a Gaussian kernel of 6-mm full-width at half maximum. Head motion was investigated

459 for any excessive movement, but movement did not exceed $3 \mathrm{~mm}$ in any participant.

\section{Extraction of region coordinates across subjects}

462 Group ICA for fMRI Toolbox (GIFT, http://mialab.mrn.org/ software/gift) (Calhoun et al. 2001) was used

463 to identify the three resting state networks of interest from placebo scans. Pre-processed resting state fMRI

464 data were spatially sorted into 20 components (Biswal et al. 2010; Shirer et al. 2012; Tsvetanov et al. 2016)

465 and spatially matched with pre-existing network templates (Shirer et al. 2012).

466 Networks were composed of cardinal regions constituting a core part of DMN (Andrews-Hanna, Reidler,

467 Sepulcre, Poulin, \& Buckner, 2010; Dixon et al., 2017) which reliably show anticorrelation with the DAN

468 and SN (Chen, Glover, Greicius, \& Chang, 2017; Dixon et al., 2017; M. D. Fox, Zhang, Snyder, \&

469 Raichle, 2009; Fransson, 2005; L. Q. Uddin, Kelly, Biswal, Castellanos, \& Milham, 2009) and followed 
medRxiv preprint doi: https://doi.org/10.1101/2021.12.28.21268391; this version posted January 3, 2022. The copyright holder for this preprint (which was not certified by peer review) is the author/funder, who has granted medRxiv a license to display the preprint in perpetuity.

It is made available under a CC-BY-NC 4.0 International license .

470 the selection of regions in a related investigation by Zhou and colleagues (Zhou et al., 2018).

471 Identification of cardinal nodes within each intrinsic network - averaged across our subjects - was

472 located using peak RSN activity of clusters within networks ( $\mathrm{p}=.05$ ) visualized using xjView toolbox

473 (https://www.alivelearn.net/xjview). Associations between peak coordinates and cardinal nodes of

474 network regions of interest (ROI) were determined by expert visual inspection. The MNI coordinates of

475 the selected ROIs are listed in Table 4.

476 A generalized linear model (GLM) was used to regress 6 head motion parameters ( 3 translation and 3

477 rotational), white matter and cerebrospinal fluid signals from preprocessed data. One subject was excluded

478 as no activation was found in one or more regions of interest. We also used global signal regression in our

479 pre-processing pipeline. The time series for each ROI was computed as the first principal component of the

480 voxel activity within a $6 \mathrm{~mm}$ sphere centred on the ROI coordinates (as listed in Table 4).

\begin{tabular}{lllll} 
Region & \multicolumn{2}{c}{ MNI coordinates } & & Network \\
\cline { 1 - 2 } & $x$ & $y$ & $z$ & \\
\hline PCC & 0 & -73 & 38 & DMN \\
IAG & 0 & 53 & 32 & DMN \\
rAG & -54 & -61 & 29 & DMN \\
dACC & 57 & -58 & 20 & DMN \\
IAI & 0 & 17 & 41 & SN \\
rAI & -48 & 14 & -7 & SN \\
IFEF & 48 & 14 & -7 & SN \\
rFEF & -30 & -10 & 68 & DAN \\
IIPS/SPL & 30 & -7 & 68 & DAN \\
rIPS/SPL & -42 & -43 & 62 & DAN \\
& 39 & -40 & 65 & DAN
\end{tabular}

482 Table 4 Coordinates of regions of interest. The DMN comprised of the posterior cingulate cortex (PCC),

483 medial prefrontal cortex (MPFC), and left and right angular gyrus (IAG/rAG); the SN comprised of the dorsal

484 anterior cingulate cortex (dACC), left and right anterior insula (IAI/rAI); and the DAN comprised the left 
medRxiv preprint doi: https://doi.org/10.1101/2021.12.28.21268391; this version posted January 3, 2022. The copyright holder for this preprint (which was not certified by peer review) is the author/funder, who has granted medRxiv a license to display the preprint in perpetuity.

It is made available under a CC-BY-NC 4.0 International license .

489 The functional connectivity matrix between regions of the DMN, SN, and DAN in the placebo condition 490 was computed for all subjects. Since our arguments rest on the premise of functional anticorrelation 491 between the resting-state networks (and similar second-order features are used for model estimation by the 492 following spectral DCM analysis), 4 subjects that did not show evidence of the anticorrelation in the placebo 493 condition were excluded from further analysis. As such, 20 subjects were left available for the following 494 DCM analysis.

Specification and Inversion of DCM

497 A fully-connected DCM was specified using the 11 ROIs defined in Table 4, without any exogenous inputs.

498 The DCM for each subject was then inverted using spectral DCM (Karl J. Friston et al., 2014; Razi, Kahan,

499 Rees, \& Friston, 2015) to infer the effective connectivity that best explains the observed cross-spectral 500 density for each subject. This procedure was repeated for each of the three testing conditions. The DCM

501 fitted the data very well and explained variance was over $85 \%$ across all subjects, and averaged $91 \%$.

Second Level Analysis Using Parametric Empirical Bayes

504 The effective connectivity inferred by spectral DCM for each subject are taken to the second (group) level

505 to test hypotheses about between-subject effects. A General Linear Model (GLM) is employed to 506 decompose individual differences in effective connectivity into hypothesised group-average connection 507 strengths plus unexplained noise. Hypotheses on the group-level parameters are tested within the Parametric 508 Empirical Bayes (PEB) framework (K. J. Friston et al., 2016), where both the expected values and the 509 covariance of the parameters are taken into account. That is, precise parameter estimates influence the 
medRxiv preprint doi: https://doi.org/10.1101/2021.12.28.21268391; this version posted January 3, 2022. The copyright holder for this preprint (which was not certified by peer review) is the author/funder, who has granted medRxiv a license to display the preprint in perpetuity.

It is made available under a CC-BY-NC 4.0 International license .

group-level result more strongly than uncertain estimates, which are down-weighted. Bayesian model

511 reduction (BMR) is used as an efficient form of Bayesian model selection (K. J. Friston et al., 2016).

Network Level Effective Connectivity and Hierarchical Organization

514 The expected network-level connectivity was computed as the sum of the expected effective connectivity

515 values between the corresponding ROIs. Then, following Zhou et. al., 2018 (Zhou et al., 2018) the

516 hierarchical connectivity strength of each network was obtained by computing the difference between its

517 averaged efferent and afferent connections (i.e., absolute values, see Supplementary S4). A similar

518 approach was used for analysing hierarchical projections in the monkey brain (Goulas, Uylings, \& Stiers,

519 2012) and prefrontal cortex hierarchical organization in humans (Nee \& D'Esposito, 2016; Zhou et al.,

520 2018).

521

References

523

Andrews-Hanna, J. R., Reidler, J. S., Sepulcre, J., Poulin, R., \& Buckner, R. L. (2010). Functionalanatomic fractionation of the brain's default network. Neuron, 65(4), 550-562. doi:10.1016/j.neuron.2010.02.005

Andrews-Hanna, J. R., Smallwood, J., \& Spreng, R. N. (2014). The default network and selfgenerated thought: component processes, dynamic control, and clinical relevance. Annals of the New York Academy of Sciences, 1316(1), 29-52. doi:10.1111/nyas.12360

Averbeck, B. B., \& Seo, M. (2008). The Statistical Neuroanatomy of Frontal Networks in the Macaque. PLOS Computational Biology, 4(4), e1000050. doi:10.1371/journal.pcbi.1000050

Batchelor, S. (2008). Buddhism without beliefs : a contemporary guide to awakening. London: Bloomsbury.

Blanke, O., \& Metzinger, T. (2009). Full-body illusions and minimal phenomenal selfhood. Trends Cogn Sci, 13(1), 7-13. doi:10.1016/j.tics.2008.10.003

Bolton, T., Wotruba, D., Buechler, R., Theodoridou, A., Michels, L., Kollias, S., . . Van De Ville, D. (2020). Triple Network Model Dynamically Revisited: Lower Salience Network State Switching in Pre-psychosis. Frontiers in Physiology, 11. doi:10.3389/fphys.2020.00066

Bonnelle, V., Ham, T. E., Leech, R., Kinnunen, K. M., Mehta, M. A., Greenwood, R. J., \& Sharp, D. J. (2012). Salience network integrity predicts default mode network function after traumatic brain injury. Proc Natl Acad Sci U S A, 109(12), 4690-4695.

doi:10.1073/pnas.1113455109 
medRxiv preprint doi: https://doi.org/10.1101/2021.12.28.21268391; this version posted January 3, 2022. The copyright holder for this preprint (which was not certified by peer review) is the author/funder, who has granted medRxiv a license to display the preprint in perpetuity. It is made available under a CC-BY-NC 4.0 International license .

Bréchet, L., Grivaz, P., Gauthier, B., \& Blanke, O. (2018). Common Recruitment of Angular Gyrus in Episodic Autobiographical Memory and Bodily Self-Consciousness. Frontiers in Behavioral Neuroscience, 12(270). doi:10.3389/fnbeh.2018.00270

Brewer, J. A., Garrison, K. A., \& Whitfield-Gabrieli, S. (2013). What about the "Self" is Processed in the Posterior Cingulate Cortex? Front Hum Neurosci, 7, 647. doi:10.3389/fnhum.2013.00647

Brewer, J. A., Worhunsky, P. D., Gray, J. R., Tang, Y.-Y., Weber, J., \& Kober, H. (2011). Meditation experience is associated with differences in default mode network activity and connectivity. Proceedings of the National Academy of Sciences, 108(50), 20254-20259. doi:10.1073/pnas.1112029108

Carhart-Harris, R. L. (2018). How do psychedelics work? Current Opinion in Psychiatry, 1. doi:10.1097/YCO.0000000000000467

Carhart-Harris, R. L., Bolstridge, M., Day, C. M. J., Rucker, J., Watts, R., Erritzoe, D. E., . . . Nutt, D. J. (2018). Psilocybin with psychological support for treatment-resistant depression: six-month follow-up. Psychopharmacology, 235(2), 399-408. doi:10.1007/s00213-0174771-x

Carhart-Harris, R. L., \& Friston, K. J. (2010). The default-mode, ego-functions and free-energy: a neurobiological account of Freudian ideas. Brain, 133(Pt 4), 1265-1283. doi:10.1093/brain/awq010

Carhart-Harris, R. L., \& Friston, K. J. (2019). REBUS and the Anarchic Brain: Toward a Unified Model of the Brain Action of Psychedelics. Pharmacological Reviews, 71(3), 316-344. doi:10.1124/pr.118.017160

Carhart-Harris, R. L., Leech, R., Erritzoe, D., Williams, T. M., Stone, J. M., Evans, J., . . . Nutt, D. J. (2012). Functional Connectivity Measures After Psilocybin Inform a Novel Hypothesis of Early Psychosis. Schizophrenia Bulletin, 39(6), 1343-1351. doi:10.1093/schbul/sbs117

Carlos Bouso, J., Palhano-Fontes, F., Rodriguez-Fornells, A., Ribeiro, S., Sanches, R., Crippa, J. A. S., . . Riba, J. (2015). Long-term use of psychedelic drugs is associated with differences in brain structure and personality in humans. European Neuropsychopharmacology, 25(4), 483-492. doi:10.1016/j.euroneuro.2015.01.008

Chaminade, T., \& Decety, J. (2002). Leader or follower? Involvement of the inferior parietal lobule in agency. Neuroreport, 13(15), 1975-1978. doi:10.1097/00001756-20021028000029

Chand, G. B., Wu, J., Hajjar, I., \& Qiu, D. (2017). Interactions of the Salience Network and Its Subsystems with the Default-Mode and the Central-Executive Networks in Normal Aging and Mild Cognitive Impairment. Brain Connectivity, 7(7), 401-412. doi:10.1089/brain.2017.0509

Chen, J. E., Glover, G. H., Greicius, M. D., \& Chang, C. (2017). Dissociated patterns of anticorrelations with dorsal and ventral default-mode networks at rest. Human Brain Mapping, 38(5), 2454-2465. doi:https://doi.org/10.1002/hbm.23532

Chong, J. S. X., Ng, G. J. P., Lee, S. C., \& Zhou, J. (2017). Salience network connectivity in the insula is associated with individual differences in interoceptive accuracy. Brain Structure and Function, 222(4), 1635-1644. doi:10.1007/s00429-016-1297-7

Cieri, F., \& Esposito, R. (2019). Psychoanalysis and Neuroscience: The Bridge Between Mind and Brain. Frontiers in Psychology, 10(1983). doi:10.3389/fpsyg.2019.01983 
medRxiv preprint doi: https://doi.org/10.1101/2021.12.28.21268391; this version posted January 3, 2022. The copyright holder for this preprint (which was not certified by peer review) is the author/funder, who has granted medRxiv a license to display the preprint in perpetuity. It is made available under a CC-BY-NC 4.0 International license .

Clark, A. (2013). Whatever next? Predictive brains, situated agents, and the future of cognitive science. Behav Brain Sci, 36(3), 181-204. doi:10.1017/s0140525x12000477

Connolly, P. (2018). Expected Free Energy Formalizes Conflict Underlying Defense in Freudian Psychoanalysis. Front Psychol, 9, 1264. doi:10.3389/fpsyg.2018.01264

Corbetta, M., \& Shulman, G. (2002). Control of Goal-Directed and Stimulus-Driven Attention in the Brain. Nature reviews. Neuroscience, 3, 201-215. doi:10.1038/nrn755

Dambrun, M. (2017). Self-centeredness and selflessness: happiness correlates and mediating psychological processes. PeerJ, 5, e3306. doi:10.7717/peerj.3306

Di, X., \& Biswal, B. B. (2014). Identifying the default mode network structure using dynamic causal modeling on resting-state functional magnetic resonance imaging. Neurolmage, 86, 53-59. doi:https://doi.org/10.1016/j.neuroimage.2013.07.071

Dittrich, A. (1998). The standardized psychometric assessment of altered states of consciousness (ASCs) in humans. Pharmacopsychiatry, 31 Suppl 2, 80-84. doi:10.1055/s2007-979351

Dixon, M. L., Andrews-Hanna, J. R., Spreng, R. N., Irving, Z. C., Mills, C., Girn, M., \& Christoff, K. (2017). Interactions between the default network and dorsal attention network vary across default subsystems, time, and cognitive states. Neurolmage, 147, 632-649. doi:10.1016/j.neuroimage.2016.12.073

Doll, A., Hölzel, B. K., Boucard, C. C., Wohlschläger, A. M., \& Sorg, C. (2015). Mindfulness is associated with intrinsic functional connectivity between default mode and salience networks. Frontiers in Human Neuroscience, 9, 461. doi:10.3389/fnhum.2015.00461

Egner, T., Monti, J. M. P., Trittschuh, E. H., Wieneke, C. A., Hirsch, J., \& Mesulam, M. M. (2008). Neural Integration of Top-Down Spatial and Feature-Based Information in Visual Search. The Journal of Neuroscience, 28(24), 6141. doi:10.1523/JNEUROSCI.1262-08.2008

Etkin, A., Egner, T., \& Kalisch, R. (2011). Emotional processing in anterior cingulate and medial prefrontal cortex. Trends in Cognitive Sciences, 15(2), 85-93. doi:10.1016/j.tics.2010.11.004

Fecteau, J. H., \& Munoz, D. P. (2006). Salience, relevance, and firing: a priority map for target selection. Trends Cogn Sci, 10(8), 382-390. doi:10.1016/j.tics.2006.06.011

Fox, M. D., Corbetta, M., Snyder, A. Z., Vincent, J. L., \& Raichle, M. E. (2006). Spontaneous neuronal activity distinguishes human dorsal and ventral attention systems. Proceedings of the National Academy of Sciences, 103(26), 10046-10051. doi:10.1073/pnas.0604187103

Fox, M. D., \& Raichle, M. E. (2007). Spontaneous fluctuations in brain activity observed with functional magnetic resonance imaging. Nature Reviews Neuroscience, 8(9), 700-711. doi:10.1038/nrn2201

Fox, M. D., Snyder, A. Z., Vincent, J. L., Corbetta, M., Van Essen, D. C., \& Raichle, M. E. (2005). The human brain is intrinsically organized into dynamic, anticorrelated functional networks. Proceedings of the National Academy of Sciences of the United States of America, 102(27), 9673. doi:10.1073/pnas.0504136102

Fox, M. D., Zhang, D., Snyder, A. Z., \& Raichle, M. E. (2009). The global signal and observed anticorrelated resting state brain networks. J Neurophysiol, 101(6), 3270-3283. doi:10.1152/jn.90777.2008 
medRxiv preprint doi: https://doi.org/10.1101/2021.12.28.21268391; this version posted January 3, 2022. The copyright holder for this preprint (which was not certified by peer review) is the author/funder, who has granted medRxiv a license to display the preprint in perpetuity. It is made available under a CC-BY-NC 4.0 International license .

Fransson, P. (2005). Spontaneous low-frequency BOLD signal fluctuations: an fMRI investigation of the resting-state default mode of brain function hypothesis. Hum Brain Mapp, 26(1), 15-29. doi:10.1002/hbm.20113

Freud, S. (1894). The neuro-psychoses of defence (Vol. 1). London: Hogarth Press.

Friston, K. (2009). The free-energy principle: a rough guide to the brain? Trends in Cognitive Sciences, 13(7), 293-301. doi:https://doi.org/10.1016/j.tics.2009.04.005

Friston, K. (2010). The free-energy principle: a unified brain theory? Nature Reviews Neuroscience, 11, 127. doi:10.1038/nrn2787

https://www.nature.com/articles/nrn2787\#supplementary-information

Friston, K., Kilner, J., \& Harrison, L. (2006). A free energy principle for the brain. J Physiol Paris, 100(1-3), 70-87. doi:10.1016/j.jphysparis.2006.10.001

Friston, K. J. (2011). Functional and effective connectivity: a review. Brain Connect, 1(1), 13-36. doi:10.1089/brain.2011.0008

Friston, K. J., Harrison, L., \& Penny, W. (2003). Dynamic causal modelling. Neurolmage, 19(4), 1273-1302. doi:10.1016/s1053-8119(03)00202-7

Friston, K. J., Kahan, J., Biswal, B., \& Razi, A. (2014). A DCM for resting state fMRI. Neurolmage, 94, 396-407. doi:https://doi.org/10.1016/j.neuroimage.2013.12.009

Friston, K. J., Litvak, V., Oswal, A., Razi, A., Stephan, K. E., van Wijk, B. C. M., . . Zeidman, P. (2016). Bayesian model reduction and empirical Bayes for group (DCM) studies. Neurolmage, 128, 413-431. doi:10.1016/j.neuroimage.2015.11.015

Goulas, A., Uylings, H. B. M., \& Stiers, P. (2012). Mapping the Hierarchical Layout of the Structural Network of the Macaque Prefrontal Cortex. Cerebral Cortex, 24(5), 11781194. doi:10.1093/cercor/bhs399

Goyal, M., Singh, S., Sibinga, E. M., Gould, N. F., Rowland-Seymour, A., Sharma, R., . . Haythornthwaite, J. A. (2014). Meditation programs for psychological stress and wellbeing: a systematic review and meta-analysis. JAMA Intern Med, 174(3), 357-368. doi:10.1001/jamainternmed.2013.13018

Greicius, M. D., \& Menon, V. (2004). Default-Mode Activity during a Passive Sensory Task: Uncoupled from Deactivation but Impacting Activation. J Cogn Neurosci, 16(9), 14841492. doi:10.1162/0898929042568532

Griffiths, R. R., Johnson, M. W., Carducci, M. A., Umbricht, A., Richards, W. A., Richards, B. D., . . . Klinedinst, M. A. (2016). Psilocybin produces substantial and sustained decreases in depression and anxiety in patients with life-threatening cancer: A randomized doubleblind trial. Journal of Psychopharmacology, 30(12), 1181-1197. doi:10.1177/0269881116675513

Grof, S. (1980). LSD Psychotherapy. Alameda, CA: Hunter House Publishers.

Ham, T. E., Bonnelle, V., Hellyer, P., Jilka, S., Robertson, I. H., Leech, R., \& Sharp, D. J. (2014). The neural basis of impaired self-awareness after traumatic brain injury. Brain : a journal of neurology, 137(Pt 2), 586-597. doi:10.1093/brain/awt350

Hasenkamp, W., Wilson-Mendenhall, C. D., Duncan, E., \& Barsalou, L. W. (2012). Mind wandering and attention during focused meditation: a fine-grained temporal analysis of fluctuating cognitive states. Neurolmage, 59(1), 750-760.

doi:10.1016/j.neuroimage.2011.07.008 
medRxiv preprint doi: https://doi.org/10.1101/2021.12.28.21268391; this version posted January 3 , 2022. The copyright holder for this preprint (which was not certified by peer review) is the author/funder, who has granted medRxiv a license to display the preprint in perpetuity. It is made available under a CC-BY-NC 4.0 International license .

673

674

675

676

677

678

679

680

681

682

683

684

685

686

687

688

689

690

691

692

693

694

695

696

697

698

699

700

701

702

703

704

705

706

707

708

709

710

711

712

713

714

715

Herzog, R., Mediano, P. A. M., Rosas, F. E., Carhart-Harris, R., Perl, Y. S., Tagliazucchi, E., \& Cofre, R. (2020). A mechanistic model of the neural entropy increase elicited by psychedelic drugs. Scientific Reports, 10(1), 17725. doi:10.1038/s41598-020-74060-6

Ho, J. T., Preller, K. H., \& Lenggenhager, B. (2020). Neuropharmacological modulation of the aberrant bodily self through psychedelics. Neurosci Biobehav Rev, 108, 526-541. doi:10.1016/j.neubiorev.2019.12.006

Ide, J. S., Shenoy, P., Yu, A. J., \& Li, C. S. (2013). Bayesian prediction and evaluation in the anterior cingulate cortex. The Journal of Neuroscience, 33(5), 2039-2047. doi:10.1523/jneurosci.2201-12.2013

Johnson, M., Richards, W., \& Griffiths, R. (2008). Human hallucinogen research: guidelines for safety. In (Vol. 22, pp. 603-620). London, England.

Josipovic, Z., Dinstein, I., Weber, J., \& Heeger, D. (2012). Influence of meditation on anticorrelated networks in the brain. Frontiers in Human Neuroscience, 5, 183. Retrieved from https://www.frontiersin.org/article/10.3389/fnhum.2011.00183

https://www.ncbi.nlm.nih.gov/pmc/articles/PMC3250078/pdf/fnhum-05-00183.pdf

Lebedev, A. V., Lövdén, M., Rosenthal, G., Feilding, A., Nutt, D. J., \& Carhart-Harris, R. L. (2015). Finding the self by losing the self: Neural correlates of ego-dissolution under psilocybin. Human Brain Mapping, 36(8), 3137-3153. doi:10.1002/hbm.22833

Legrand, D., \& Ruby, P. (2009). What is self-specific? Theoretical investigation and critical review of neuroimaging results [American Psychological Association doi:10.1037/a0014172]. Retrieved

Leptourgos, P., Fortier-Davy, M., Carhart-Harris, R., Corlett, P., Dupuis, D., Halberstadt, A., . . Jardri, R. (2020). Hallucinations Under Psychedelics and in the Schizophrenia Spectrum: An Interdisciplinary and Multiscale Comparison. Schizophrenia Bulletin. doi:10.1093/schbul/sbaa117

Liang, X., He, Y., Salmeron, B. J., Gu, H., Stein, E. A., \& Yang, Y. (2015). Interactions between the salience and default-mode networks are disrupted in cocaine addiction. The Journal of neuroscience : the official journal of the Society for Neuroscience, 35(21), 8081-8090. doi:10.1523/JNEUROSCI.3188-14.2015

Manoliu, A., Riedl, V., Zherdin, A., Mühlau, M., Schwerthöffer, D., Scherr, M., . . Sorg, C. (2014). Aberrant dependence of default mode/central executive network interactions on anterior insular salience network activity in schizophrenia. Schizophr Bull, 40(2), 428437. doi:10.1093/schbul/sbt037

Menon, V. (2011). Large-scale brain networks and psychopathology: a unifying triple network model. Trends Cogn Sci, 15(10), 483-506. doi:10.1016/j.tics.2011.08.003

Menon, V. (2015). Salience Network (Vol. 2): Elsevier.

Menon, V. (2018). The Triple Network Model, Insight, and Large-Scale Brain Organization in Autism. Biological Psychiatry, 84(4), 236-238. doi:10.1016/j.biopsych.2018.06.012

Menon, V., \& Uddin, L. Q. (2010). Saliency, switching, attention and control: a network model of insula function. Brain structure \& function, 214(5-6), 655-667. doi:10.1007/s00429-0100262-0

Metzinger, T. (2003). Being no one: The self-model theory of subjectivity. Cambridge, MA, US: MIT Press. 
medRxiv preprint doi: https://doi.org/10.1101/2021.12.28.21268391; this version posted January 3, 2022. The copyright holder for this preprint (which was not certified by peer review) is the author/funder, who has granted medRxiv a license to display the preprint in perpetuity. It is made available under a CC-BY-NC 4.0 International license .

Millière, R. (2017). Looking for the Self: Phenomenology, Neurophysiology and Philosophical Significance of Drug-induced Ego Dissolution. Frontiers in Human Neuroscience, 11(245). doi:10.3389/fnhum.2017.00245

Millière, R., Carhart-Harris, R. L., Roseman, L., Trautwein, F.-M., \& Berkovich-Ohana, A. (2018). Psychedelics, Meditation, and Self-Consciousness. Frontiers in Psychology, 9(1475). doi:10.3389/fpsyg.2018.01475

Müller, F., Dolder, P. C., Schmidt, A., Liechti, M. E., \& Borgwardt, S. (2018). Altered network hub connectivity after acute LSD administration. Neurolmage. Clinical, 18, 694-701. doi:10.1016/j.nicl.2018.03.005

Nee, D. E., \& D'Esposito, M. (2016). The hierarchical organization of the lateral prefrontal cortex. elife, 5. doi:10.7554/eLife.12112

Northoff, G., Heinzel, A., de Greck, M., Bermpohl, F., Dobrowolny, H., \& Panksepp, J. (2006). Self-referential processing in our brain--a meta-analysis of imaging studies on the self. Neurolmage, 31(1), 440-457. doi:10.1016/j.neuroimage.2005.12.002

Nour, M. M., \& Carhart-Harris, R. L. (2017). Psychedelics and the science of self-experience. Br J Psychiatry, 210(3), 177-179. doi:10.1192/bjp.bp.116.194738

Nour, M. M., Evans, L., Nutt, D., \& Carhart-Harris, R. L. (2016). Ego-Dissolution and Psychedelics: Validation of the Ego-Dissolution Inventory (EDI). Frontiers in Human Neuroscience, 10. doi:10.3389/fnhum.2016.00269

Nutt, D., \& Carhart-Harris, R. (2020). The Current Status of Psychedelics in Psychiatry. JAMA Psychiatry. doi:10.1001/jamapsychiatry.2020.2171

Palaniyappan, L., \& Liddle, P. F. (2012). Does the salience network play a cardinal role in psychosis? An emerging hypothesis of insular dysfunction. J Psychiatry Neurosci, 37(1), 17-27. doi:10.1503/jpn.100176

Palhano-Fontes, F., Andrade, K. C., Tofoli, L. F., Santos, A. C., Crippa, J. A., Hallak, J. E., . . . de Araujo, D. B. (2015). The psychedelic state induced by ayahuasca modulates the activity and connectivity of the default mode network. Plos One, 10(2), e0118143. doi:10.1371/journal.pone.0118143

Peterson, A., Thome, J., Frewen, P., \& Lanius, R. A. (2014). Resting-State Neuroimaging Studies: A New Way of Identifying Differences and Similarities among the Anxiety Disorders? The Canadian Journal of Psychiatry, 59(6), 294-300. doi:10.1177/070674371405900602

Preller, K. H., Burt, J. B., Ji, J. L., Schleifer, C. H., Adkinson, B. D., Stämpfli, P., . . Anticevic, A. (2018). Changes in global and thalamic brain connectivity in LSD-induced altered states of consciousness are attributable to the 5-HT2A receptor. eLife, 7, e35082. doi:10.7554/eLife.35082

Preller, K. H., Herdener, M., Pokorny, T., Planzer, A., Kraehenmann, R., Stampfli, P., . . . Vollenweider, F. X. (2017). The Fabric of Meaning and Subjective Effects in LSD-Induced States Depend on Serotonin 2A Receptor Activation. Curr Biol, 27(3), 451-457. doi:10.1016/j.cub.2016.12.030

Preller, K. H., Pokorny, T., Hock, A., Kraehenmann, R., Stampfli, P., Seifritz, E., . . Vollenweider, F. X. (2016). Effects of serotonin 2A/1A receptor stimulation on social exclusion processing. Proc Natl Acad Sci U S A, 113(18), 5119-5124. doi:10.1073/pnas.1524187113

Preller, K. H., Pokorny, T., Kraehenmann, R., Scheidegger, M., Dziobek, I., Staempfli, P., \& Vollenweider, F. X. (2015). The 5-HT2A/1A agonist psilocybin reduces social pain and 
medRxiv preprint doi: https://doi.org/10.1101/2021.12.28.21268391; this version posted January 3 , 2022. The copyright holder for this preprint (which was not certified by peer review) is the author/funder, who has granted medRxiv a license to display the preprint in perpetuity. It is made available under a CC-BY-NC 4.0 International license .

enhances empathy in healthy volunteers. European Neuropsychopharmacology, 25, S301-S301. doi:10.1016/s0924-977x(15)30364-3

Preller, K. H., Razi, A., Zeidman, P., Stämpfli, P., Friston, K. J., \& Vollenweider, F. X. (2019). Effective connectivity changes in LSD-induced altered states of consciousness in humans. Proceedings of the National Academy of Sciences, 116(7), 2743-2748. doi:10.1073/pnas.1815129116

Preller, K. H., \& Vollenweider, F. X. (2018). Phenomenology, Structure, and Dynamic of Psychedelic States. Curr Top Behav Neurosci, 36, 221-256. doi:10.1007/7854_2016_459

Putcha, D., Ross, R. S., Cronin-Golomb, A., Janes, A. C., \& Stern, C. E. (2016). Salience and Default Mode Network Coupling Predicts Cognition in Aging and Parkinson's Disease. Journal of the International Neuropsychological Society : JINS, 22(2), 205-215. doi:10.1017/S1355617715000892

Raichle, M. E. (2015). The brain's default mode network. Annu Rev Neurosci, 38, 433-447. doi:10.1146/annurev-neuro-071013-014030

Raichle, M. E., MacLeod, A. M., Snyder, A. Z., Powers, W. J., Gusnard, D. A., \& Shulman, G. L. (2001). A default mode of brain function. Proc Natl Acad Sci U S A, 98(2), 676-682. doi:10.1073/pnas.98.2.676

Ramirez Barrantes, R., Arancibia, M., Stojanova, J., Aspé-Sánchez, M., Córdova, C., \& Henríquez, R. A. (2019). Default Mode Network, Meditation, and Age-Associated Brain Changes: What Can We Learn from the Impact of Mental Training on Well-Being as a Psychotherapeutic Approach? Neural Plasticity, 2019, 1-15. doi:10.1155/2019/7067592

Razi, A., Kahan, J., Rees, G., \& Friston, K. J. (2015). Construct validation of a DCM for resting state fMRI. Neurolmage, 106, 1-14. doi:https://doi.org/10.1016/j.neuroimage.2014.11.027

Roseman, L., Nutt, D. J., \& Carhart-Harris, R. L. (2018). Quality of Acute Psychedelic Experience Predicts Therapeutic Efficacy of Psilocybin for Treatment-Resistant Depression. Frontiers in Pharmacology, 8, 974. doi:10.3389/fphar.2017.00974

Ross, S., Bossis, A., Guss, J., Agin-Liebes, G., Malone, T., Cohen, B., . . Schmidt, B. L. (2016). Rapid and sustained symptom reduction following psilocybin treatment for anxiety and depression in patients with life-threatening cancer: a randomized controlled trial. Journal of Psychopharmacology, 30(12), 1165-1180. doi:10.1177/0269881116675512

Ruban, A., \& Kolodziej, A. A. (2018). Changes in default-mode network activity and functional connectivity as an indicator of psychedelic-assisted psychotherapy effectiveness. Neuropsychiatria I Neuropsychologia, 13(3), 91-97. doi:10.5114/nan.2018.81249

Safron, A. (2020, November 30). On the Varieties of Conscious Experiences: Altered Beliefs Under Psychedelics (ALBUS). https://doi.org/10.31234/osf.io/zqh4b

Scalabrini, A., Vai, B., Poletti, S., Damiani, S., Mucci, C., Colombo, C., . . Northoff, G. (2020). All roads lead to the default-mode network-global source of DMN abnormalities in major depressive disorder. Neuropsychopharmacology, 45(12), 2058-2069. doi:10.1038/s41386-020-0785-x

Seeley, W. W., Menon, V., Schatzberg, A. F., Keller, J., Glover, G. H., Kenna, H., ... Greicius, M. D. (2007). Dissociable intrinsic connectivity networks for salience processing and executive control. The Journal of Neuroscience, 27(9), 2349-2356. doi:10.1523/jneurosci.5587-06.2007 
medRxiv preprint doi: https://doi.org/10.1101/2021.12.28.21268391; this version posted January $3,2022$. The copyright holder for this preprint (which was not certified by peer review) is the author/funder, who has granted medRxiv a license to display the preprint in perpetuity. It is made available under a CC-BY-NC 4.0 International license .

Sridharan, D., Levitin, D. J., \& Menon, V. (2008). A critical role for the right fronto-insular cortex in switching between central-executive and default-mode networks. Proceedings of the National Academy of Sciences, 105(34), 12569. doi:10.1073/pnas.0800005105

Stoliker, D., Egan, G., Friston, K., \& Razi, A. (2021). Neural Mechanisms and Psychology of Psychedelic Ego Dissolution. In: PsyArXiv.

Stoliker, D., Egan, G., \& Razi, A. (2021). Reduced precision underwrites ego dissolution and therapeutic outcomes under psychedelics. In: PsyArXiv.

Studerus, E., Gamma, A., \& Vollenweider, F. X. (2010). Psychometric evaluation of the altered states of consciousness rating scale (OAV). Plos One, 5(8), e12412-e12412. doi:10.1371/journal.pone.0012412

Swanson, L. R. (2018). Unifying Theories of Psychedelic Drug Effects. Frontiers in Pharmacology, 9(172). doi:10.3389/fphar.2018.00172

Swick, D., Ashley, V., \& Turken, U. (2011). Are the neural correlates of stopping and not going identical? Quantitative meta-analysis of two response inhibition tasks. Neurolmage, 56(3), 1655-1665. doi:10.1016/j.neuroimage.2011.02.070

Szczepanski, S. M., Pinsk, M. A., Douglas, M. M., Kastner, S., \& Saalmann, Y. B. (2013). Functional and structural architecture of the human dorsal frontoparietal attention network. Proceedings of the National Academy of Sciences, 110(39), 15806. doi:10.1073/pnas.1313903110

Thompson, K. G., Biscoe, K. L., \& Sato, T. R. (2005). Neuronal basis of covert spatial attention in the frontal eye field. The Journal of Neuroscience, 25(41), 9479-9487. doi:10.1523/jneurosci.0741-05.2005

Uddin, L. Q., Kelly, A. M., Biswal, B. B., Castellanos, F. X., \& Milham, M. P. (2009). Functional connectivity of default mode network components: correlation, anticorrelation, and causality. Hum Brain Mapp, 30(2), 625-637. doi:10.1002/hbm.20531

Uddin, L. Q., Molnar-Szakacs, I., Zaidel, E., \& lacoboni, M. (2006). rTMS to the right inferior parietal lobule disrupts self-other discrimination. Social cognitive and affective neuroscience, 1(1), 65-71. doi:10.1093/scan/nsl003

Vogt, B. A., \& Pandya, D. N. (1987). Cingulate cortex of the rhesus monkey: II. Cortical afferents. Journal of Comparative Neurology, 262(2), 271-289. doi:https://doi.org/10.1002/cne.902620208

Vollenweider, F. X. (1998). Advances and pathophysiological models of hallucinogenic drug actions in humans: a preamble to schizophrenia research. Pharmacopsychiatry, 31 Suppl 2, 92-103. doi:10.1055/s-2007-979353

Vollenweider, F. X., Leenders, K. L., Scharfetter, C., Maguire, P., Stadelmann, O., \& Angst, J. (1997). Positron emission tomography and fluorodeoxyglucose studies of metabolic hyperfrontality and psychopathology in the psilocybin model of psychosis. Neuropsychopharmacology, 16(5), 357-372. doi:10.1016/s0893-133x(96)00246-1

Vollenweider, F. X., \& Preller, K. H. (2020). Psychedelic drugs: neurobiology and potential for treatment of psychiatric disorders. Nature Reviews Neuroscience, 21(11), 611-624. doi:10.1038/s41583-020-0367-2

Wotruba, D., Michels, L., Buechler, R., Metzler, S., Theodoridou, A., Gerstenberg, M., .. . Heekeren, K. (2013). Aberrant Coupling Within and Across the Default Mode, Task- 
medRxiv preprint doi: https://doi.org/10.1101/2021.12.28.21268391; this version posted January 3, 2022. The copyright holder for this preprint (which was not certified by peer review) is the author/funder, who has granted medRxiv a license to display the preprint in perpetuity. It is made available under a CC-BY-NC 4.0 International license .

Positive, and Salience Network in Subjects at Risk for Psychosis. Schizophrenia Bulletin,

849 Yaden, D. B., \& Griffiths, R. R. (2020). The Subjective Effects of Psychedelics Are Necessary for $850 \quad$ Their Enduring Therapeutic Effects. ACS Pharmacology \& Translational Science.

851 doi:10.1021/acsptsci.0c00194

852 Yaoi, K., Osaka, M., \& Osaka, N. (2015). Neural correlates of the self-reference effect: evidence 853 from evaluation and recognition processes. Frontiers in Human Neuroscience, 9(383). doi:10.3389/fnhum.2015.00383

855 Zhou, Y., Friston, K. J., Zeidman, P., Chen, J., Li, S., \& Razi, A. (2018). The Hierarchical Organization of the Default, Dorsal Attention and Salience Networks in Adolescents and Young Adults. Cereb Cortex, 28(2), 726-737. doi:10.1093/cercor/bhx307 